Article

\title{
Effects of Sterilization on Bioactives of Jatropha dioica and Opuntia oligacantha Extracts, and on Antimicrobial Capacity against Streptococcus mutans
}

\author{
Jorge Terrazas-Hernández ${ }^{1}$, Eva M. Santos-López ${ }^{2}$, Raquel Cariño-Cortés ${ }^{1}$, \\ Rubén Jiménez-Alvarado ${ }^{3}$, César Uriel López-Palestina ${ }^{4}(\mathbb{D})$ and \\ Alma Delia Hernández-Fuentes ${ }^{3, *}$ \\ 1 Instituto de Ciencias de la Salud, Universidad Autónoma del Estado de Hidalgo, Circuito Ex Hacienda la \\ Concepción s/n Carretera Pachuca-Actopan San Agustín Tlaxiaca, Hidalgo C.P. 42160, Mexico; \\ jorge_terrazas86@hotmail.com (J.T.-H.); raquelcarcortes@gmail.com (R.C.-C.) \\ 2 Instituto de Ciencias Básicas e Ingeniería, Universidad Autónoma del Estado de Hidalgo, Carretera \\ Pachuca-Tulancingo km 4.5., Hidalgo C.P. 42084, Mexico; emsantos@ueah.edu.mx \\ 3 Instituto de Ciencias Agropecuarias, Universidad Autónoma del Estado de Hidalgo, Av. Universidad Km. 1, \\ Rancho Universitario, Tulancingo, Hidalgo C.P. 43600, Mexico; rjalvarado@gmail.com \\ 4 Tecnológico Nacional de México/I. T. Roque, km. 8 Carretera Celaya-Juventino Rosas, Celaya, \\ Guanajuato C.P. 38110, Mexico; clopez_17p@outlook.com \\ * Correspondence: hfad@hotmail.com
}

Received: 15 November 2018; Accepted: 4 December 2018; Published: 6 December 2018

\begin{abstract}
Natural extracts have been used as antimicrobial agents, and extracts of the rhizomes of the dragon's blood plant (Jatropha dioica) and of the fruit of xoconostle 'Ulapa' (Opuntia oligacantha) are among these agents. To be able to use the extracts, it is necessary to eliminate their natural microbiota by the means of sterilization methods; however, the effects of thermal sterilization on their properties have not been evaluated. The objective of the study was to evaluate the physico-chemical, antioxidant, and antimicrobial properties of extracts of the rhizomes of dragon's blood and the fruit of xoconostle, when not sterilized, and when sterilized by autoclaving. The contents of phenolic compounds, flavonoids, antioxidant, and antimicrobial activity against Streptococcus mutans were not affected in autoclave-sterilized extracts of dragon's blood rhizomes, and naringenin, apigenin, galagina, vanillic, and caffeic acid were detected, while in autoclave-sterilized extracts of xoconostle fruits, the betalain content decreased, with galagin, gallic, vanillic, and p-coumaric acid being identified. The minimum inhibitory concentration for the extract sterilized by autoclaving dragon's blood was $2 \mathrm{mg} / \mathrm{mL}$, and for the extract sterilized by autoclaving xoconostle, it was $28 \mathrm{mg} / \mathrm{mL}$. Both represent natural alternatives as antimicrobial agents against $S$. mutans.
\end{abstract}

Keywords: dragon's blood; Streptococcus mutans; xoconostle; phenolic compounds; antioxidant activity

\section{Introduction}

Streptococcus mutans is a Gram-positive bacterial involved in oral health issues, as it is responsible for tooth decay, which triggers other illnesses such as gingivitis and periodontitis [1]. Some of the most commonly used chemical agents to control plaque and tooth decay related to S. mutans are chlorhexidine and triclosan; however, long-term use of these substances causes secondary effects such as brown staining in teeth, altered taste, and scaly lesions in the alveolar mucosa [2]. Currently, the use of natural antimicrobial agents with efficient performance in the inhibition of pathogenic 
microorganisms has become an interesting alternative, due to the secondary effects caused by antibiotics, and the development of bacterial resistance [3].

In this regard, around 30,000 plant species are found in Mexico; from these, 33\% are considered to have medicinal properties, and only $5 \%$ have been accounted for, with chemical, pharmaceutical, and biomedical validation $[4,5]$. Among them, we can find several plants that grow in the wild, in arid and semi-arid regions of Mexico. The acidic cactus pear, or xoconostle 'Ulapa', is an acid fruit of the cactus known as nopal, and it has anti-inflammatory, antioxidant, and antimicrobial properties $[6,7]$. The health benefits associated with this fruit are related to its contents of fiber, phenols, flavonoids, betanins, vulgaxanthins, and ascorbic acid [8]. Morales et al. [7] found a higher content of ascorbic acid in the pulp, while seeds presented a higher content of phenols and flavonoids. On the other hand, Hernández-Fuentes et al. [8] detected a high total phenolic content (278 mg GAE/100 g) and antioxidant activity (9.80 mmol TE/100 g) in xoconostle 'Ulapa' pulp. Hayek and Ibrahim [6] reported that aqueous extracts of xoconostle present an inhibitory effect when used at a concentration of $10 \%$ $(v / v)$ against E. coli O157: H7. However, the main use of xoconostle lies in Mexican cuisine as a condiment, with the development of traditional candies, sauces, and jams being an underutilized resource $[7,8]$.

On the other hand, Jatropha dioica is a plant known as dragon's blood, and it has been employed in Mexican traditional medicine as a stem infusion or rhizome mastication to prevent tooth mobility, and as an analgesic for pain relief [9]. Some species of Jatropha have been demonstrated, in methanolic extracts of the rhizomes, to trigger anti-inflammatory activity in rats with a dose of $200 \mathrm{mg} / \mathrm{kg}$ body weight [10]. Furthermore, the hydroalcoholic extracts of dragon's blood rhizomes present antioxidant and antimicrobial activities at a concentration of $50 \mathrm{mg} / \mathrm{mL}$ against fungi, and against Gram-positive and Gram-negative bacteria [11,12]. The antioxidant and antimicrobial properties of Jatropha dioica are related mainly to its content of phenolic compounds [13].

One of the problems that arises when using natural extracts of plants as an antimicrobial substance is contamination by fungi and molds, probably during the extraction of fresh materials, since aseptic techniques are not followed during the extraction processes [14]. Autoclave sterilization can solve this problem in plant extracts [14]. However, autoclave sterilization uses high process temperatures, which may cause some modifications in the bioactive compounds of the plant extracts. In this context, many functional ingredients, such as polyphenols and flavonoids, are thermally sensitive, and the amounts of these active components that remain during the process of thermal sterilization at high temperatures are important for the maintenance of their antioxidant, antimicrobial, and other properties, which are linked to health benefits [15]. Extracts of xoconostle and dragon's blood can be a viable alternative against Streptococcus mutans, due to its antimicrobial and antioxidant properties; however, it is still unknown as to whether autoclave-sterilization affects the functional properties of these extracts.

Thus, the objective of this study was to evaluate the effects of autoclave-sterilization on the bioactives in the rhizomes of dragon's blood plant and xoconostle fruit extracts, and their antimicrobial capacities against Streptococcus mutans, in order to be used as safe and active ingredients.

\section{Materials and Methods}

\subsection{Plant Material}

Dragon's blood rhizomes (Jatropha dioica Sessé ex Cerv. Var. dioica) were collected during February 2017 (dry period), in the Municipality of Morelos, Zacatecas, Mexico, located at the coordinates $22^{\circ} 53^{\prime} 00^{\prime \prime} \mathrm{N}$ and $102^{\circ} 36^{\prime} 00^{\prime \prime} \mathrm{W}$, at $2348 \mathrm{~m}$ above sea level (a.s.l.), with dry and semi-dry weather and phaeozem soil. The specimens were identified and preserved in the herbarium at Autonomous University of the State of Hidalgo with the record code "AD Hernández Fuentes 01". The rhizomes were stored at ultra-low temperature $\left(-70^{\circ} \mathrm{C}\right.$ ) (Thermo Scientific 703 Ultra-Low Freezer, Grand Island, NY, USA), lyophilized (Model 79480 LABCONCO, Kansas City, MO, USA), and stored at $5{ }^{\circ} \mathrm{C}$ for one week before use. 
Xoconostle fruits (Opuntia oligacantha CF Först var. 'Ulapa') were sampled during February 2017 at Ulapa Melchor Ocampo Hidalgo, in the Municipality of Tetepango, Hidalgo, Mexico, located at the coordinates $20^{\circ} 40^{\prime} 55^{\prime \prime} \mathrm{N}$ and $99^{\circ} 04^{\prime} 59^{\prime \prime} \mathrm{W}$, at $2100 \mathrm{~m}$ a.s.l., with semi-dry temperate weather and alluvial soil. Xoconostle fruits were identified according to Hernández-Fuentes et al. 2015. Fruit at the stage of commercial maturity (completely colored) were selected and washed, and the glochids were removed. The fruits were stored at ultra-low temperature $\left(-70^{\circ} \mathrm{C}\right)$ (Thermo Scientific 703 Ultra-Low Freezer, Grand Island, NY, USA), lyophilized (Model 79480 LABCONCO, Kansas City, MO, USA), and stored $\left(5^{\circ} \mathrm{C}\right.$ for one week before use).

\subsection{Extraction Procedure}

Extracts of dragon's blood rhizomes were obtained following the methodology suggested by Wong-Paz et al. [12], with subtle modifications. The experimental conditions allowed for higher yields and the contents of the bioactive compounds to be obtained, and modifications were made in the drying of the rhizomes; they were not dried at $60^{\circ} \mathrm{C}$, and lyophilization was used instead. Extraction was performed using $70 \%$ ethanol at a rhizome/solvent ratio of 1:5. The liquid fraction was filtered using Whatman paper $n^{\circ} 5$, and the solvent was brought to dryness in a rotary evaporator (Büchi R-215, Flawil, Switzerland) at $50^{\circ} \mathrm{C}$ under vacuum conditions. The extract was recovered from the rotavapor flask and weighed, redissolved with distilled water at a concentration of $0.2-5 \mathrm{mg}$ of dry extract $/ \mathrm{mL}$, and sonicated in a bath sonicator (Ultrasonic Cleaner, Mod. 32V118A, Freeport, IL, USA) for complete dissolution at $30{ }^{\circ} \mathrm{C}$ for $20 \mathrm{~min}$.

Xoconostle extracts were obtained from lyophilized whole fruit (peel, pulp, and seeds). The lyophilized fruit was ground, resuspended in water, and centrifuged (Thermo Scientific, Mod. ST $16 R$, Waltham, MA, USA) at $17,500 \times g$ for $10 \mathrm{~min}$ at $5{ }^{\circ} \mathrm{C}$. The supernatant was separated, and the procedure was repeated with the precipitate until there was total loss of color in the liquid phase. The resulting supernatants were collected and lyophilized. The dry samples were ground, weighed, and redissolved with distilled water at a concentration of $0.2-80 \mathrm{mg}$ dry extract $/ \mathrm{mL}$, and sonicated for complete dissolution.

\subsection{Non-Sterilized or Autoclave-Sterilized Extracts}

Previous microbiological analyses of the extracts showed the presence of microorganisms due to contamination during their extraction; for this reason, the extracts were subjected to a sterilization process by autoclaving. The conditions of the autoclave sterilization were $121^{\circ} \mathrm{C}$ for $15 \mathrm{~min}$ at 15 psi (Tuttnaver, 354SE, Hauppauge, NY, USA). On the other hand, the non-sterilized extracts were filtered through $0.20 \mu \mathrm{m}$ acrodiscs (syringe filter). The nomenclature used to identify the non-sterilized extracts of dragon's blood plant rhizomes and xoconostle fruit were $S_{A}$ and $X_{A}$, respectively; autoclave-sterilized extracts of dragon's blood rhizomes and xoconostle fruit were $S_{B}$ and $\mathrm{X}_{\mathrm{B}}$, respectively.

\subsection{Determination of Physicochemical Properties}

Physical-chemical properties were determined for the non-sterilized and autoclave-sterilized extracts. $\mathrm{pH}$ was measured according to the AOAC 920.151 method [16], using a digital potentiometer (Hanna Instruments Woonsocket, RI, USA). The total sugar content was determined by spectrophotometry, following the method described by Dimler et al. [17] (antrone- $\mathrm{H}_{2} \mathrm{SO}_{4}$ assay), measuring its absorbance at $640 \mathrm{~nm}$ (model $6715 \mathrm{UV} /$ Vis, Jenway, Techne Inc., Staffordshire, UK). The concentration of the reducing sugars was detected by spectrophotometry, according to the method suggested by Miller [18] with 3,5-dinitrosalicylic acid (DNS) at $540 \mathrm{~nm}$. Glucose was employed as a standard for the latter two estimations.

Ascorbic acid content was determined by spectrophotometry following the methodology developed by Jagota and Dani [19]. Briefly, $0.1 \mathrm{~mL}$ of the extract was used, which was diluted in $10 \mathrm{~mL}$ of trichloroacetic acid $(10 \% \mathrm{w} / \mathrm{v})$, and allowed to react for $10 \mathrm{~min}$, and its absorbance was 
subsequently measured at $760 \mathrm{~nm}$. The color attributes of the extracts (values of $L^{*}, a^{*}$, and $b^{*}$ ) were measured using a Hunter Lab colorimeter (Minolta, CM508d, Minolta Camera Co., Ltd., Osaka, Japan) total color difference $(\Delta \mathrm{E})$ was obtained with Equation (1):

$$
\Delta E=\sqrt{\Delta L^{* 2}+\Delta a^{* 2}+\Delta b^{* 2}}
$$

where $\Delta L^{*}$ is the difference in lightness, $\Delta a^{*}$ is the difference in red, and $\Delta b^{*}$ is the difference in yellow detected in extracts that were non-sterilized and sterilized by autoclaving.

\subsection{Total Phenolic Analysis}

Phenolic compounds content was determined for non-sterilized and sterilized extracts of dragon's blood rhizomes and xoconostle fruit. The total phenolic content was estimated using the methodology proposed by Singleton and Rossi [20]. Extracts dissolved in distilled water $(0.5 \mathrm{~mL})$ were mixed with $2.5 \mathrm{~mL}$ Folin-Ciocalteu reagent and $2 \mathrm{~mL}$ of $\mathrm{Na}_{2} \mathrm{CO}_{3}(0.7 \mathrm{~N})$, and maintained under darkness conditions for $2 \mathrm{~h}$. The absorbance was measured at $760 \mathrm{~nm}$ using a spectrophotometer (model 6715 UV/Vis, Jenway, Techne Inc., Staffordshire, UK). The total phenolic content was expressed as mg $\mathrm{GAE} / \mathrm{g}$.

\subsection{Flavonoid Content}

Flavonoid content was estimated according to the methodology adapted by Arvouet-Grand et al. [21]. A solution containing extracts dissolved in distilled water $(2 \mathrm{~mL})$ and $\mathrm{AlCl}_{3}(2 \%)$ in pure methanol was prepared. The absorbance was measured at a $415 \mathrm{~nm}$ using a spectrophotometer. Results were expressed as $\mathrm{mg} \mathrm{QE} / \mathrm{g}$.

\subsection{Quantification of Betalain}

Betalains were quantified exclusively for non-sterilized and sterilized extracts of xoconostle fruit, following the methodology suggested by Nilsson [22] for estimating the concentration of betanins and vulgaxanthins (dragon's blood plant has anthocyanins, thus excluding the presence of betalains). Xoconostle extracts were dissolved in distilled water. Measurements were recorded at 476, 538, and $600 \mathrm{~nm}$ using a spectrophotometer $\left(\mathrm{A}_{476}, \mathrm{~A}_{538}\right.$, and $\mathrm{A}_{600}$ were the absorbance values obtained at these wavelengths, respectively). Betanins and vulgaxanthins were determined using Equations (2) and (3), modified by Nilsson. The content is expressed as $\mathrm{mg} / 100 \mathrm{~g}$ dry extract (DE).

$$
\begin{gathered}
\text { Betanins }=\left[\left(\frac{a}{1.129}\right)(D F)\left(1 \times 10^{5}\right)\right] \\
\text { Vulgaxanthins }=\left[\left(\frac{y}{750}\right)(D F)\left(1 \times 10^{5}\right)\right]
\end{gathered}
$$

where $a=1.095\left(\mathrm{~A}_{538}-\mathrm{A}_{600}\right) ; y=\mathrm{A}_{476}-\left(\mathrm{A}_{538}-a\right)-(a / 3.1)$ and $D F=$ dilution factor.

\subsection{Identification of Extract Compounds by HPLC}

Compounds of non-sterilized and autoclave-sterilized extracts were identified by high-performance liquid chromatography (HPLC). Extracts $S_{A}, S_{B}, X_{A}$, and $X_{B}$ were prepared at a concentration of $5 \mathrm{mg} / \mathrm{mL}$ in distilled water, centrifuged at $17,500 \times \mathrm{g}$ for $15 \mathrm{~min}$, and filtered $(0.2 \mu \mathrm{m})$. The extract content and type of metabolites were identified by HPLC, according to the methodology described by Aguiñiga-Sánchez et al. [23]. Flavonoids were determined in a HP Hypersil ODS column $(125 \times 40 \mathrm{~mm})$ under gradient conditions of $(\mathrm{A}) \mathrm{H}_{2} \mathrm{O}$ at $\mathrm{pH} 2.5$ with trifluoroacetic acid (TFA), and $(\mathrm{B})$ acetonitrile $(\mathrm{ACN})$ with the following parameters: injection volume was $20 \mu \mathrm{L}$, flow rate was fixed at $1 \mathrm{~mL} / \mathrm{min}$, reaction temperature was $30^{\circ} \mathrm{C}$, and analysis period was $25 \mathrm{~min}$. Standards were rutin, phlorizidin, myricetin, quercetin, naringenin, phloretin, apigenin, and galagin (Sigma Aldrich, St. Louis, MO, USA). Phenolic acids were determined with a Nucleosil (Macherey-Nagel) 
column $(125 \times 4.0 \mathrm{~mm})$ under gradient conditions of $(\mathrm{A}) \mathrm{H}_{2} \mathrm{O}$ at $\mathrm{pH} 2.5$ with TFA and (B) ACN. The experimental parameters were the same as for the flavonoids, while the standards were caffeic, gallic, chlorogenic, vanillic, p-hydroxybenzoic, p-coumaric, ferulic, and syringic acids (Sigma Aldrich).

\subsection{Determination of Antioxidant Activity by the DPPH Method}

The antioxidant activities were determined for the non-sterilized and autoclave-sterilized extracts of dragon's blood rhizomes and xoconostle fruit. The 2,20-diphenyl-1-picrylhydrazyl (DPPH) method suggested by Brand Williams et al. [24], was employed for the estimations. A total of $300 \mu \mathrm{L}$ of extract prepared in distilled water with $2.7 \mathrm{~mL}$ DPPH solution and maintained under darkness for $60 \mathrm{~min}$, was used. The absorbance was measured at $517 \mathrm{~nm}$ using a spectrophotometer; the antioxidant activity was expressed as $\mathrm{mg} \mathrm{TE} / \mathrm{g}$.

\subsection{Determination of Antioxidant Activity by the ABTS Method}

The 2,2'-azino-bis(3-ethylbenzothiazoline-6-sulphonic acid) (ABTS) method was carried out according to Re et al. [25]. A total of $100 \mu \mathrm{L}$ of extracts prepared with distilled water and mixed with $3.9 \mathrm{~mL}$ of ABTS solution (previously prepared with $\mathrm{K}_{2} \mathrm{~S}_{2} \mathrm{O}_{8}(2.45 \mathrm{mM})$ was used. The absorbance was measured in a spectrophotometer at $754 \mathrm{~nm}$. The results were expressed as $\mathrm{mg} \mathrm{TE} / \mathrm{g}$.

\subsection{Antimicrobial Activity}

The antimicrobial activities of the non-sterilized and autoclave-sterilized extracts of dragon's blood rhizomes and xoconostle fruit were determined according to the methodology developed by Domínguez et al. [26]. A mixture was prepared by combining $10 \mathrm{~mL}$ of Brain Heart Infusion (BHI) broth, $5 \mathrm{mg} / \mathrm{mL}$ non-sterilized or autoclave-sterilized extract, and $100 \mu \mathrm{L}$ of liquid medium containing Streptococcus mutans (ATCC 25175, lot number: 62284317) at a concentration of 103 colony-forming units (CFU) per mL. Samples were incubated at $37^{\circ} \mathrm{C}$ for $80 \mathrm{~h}$. Changes in turbidity were measured every $4 \mathrm{~h}$ in the spectrophotometer at $600 \mathrm{~nm}$, using a quartz cell $(1000 \mu \mathrm{L})$.

Each extract was evaluated with the following: a blank containing BHI broth and the extract without Streptococcus mutans, a positive control containing $10 \mathrm{~mL}$ of $\mathrm{BHI}$ broth and $103 \mathrm{CFU} / \mathrm{mL}$ of S. mutans, and a negative control containing $10 \mathrm{~mL}$ of BHI broth, $103 \mathrm{CFU} / \mathrm{mL}$ of $S$. mutans, and $0.012 \mu \mathrm{L}$ of chlorhexidine/mL (GUM Paroex, Sunstar Suisse S.A., Étoy, Switzerland). The concentration of chlorhexidine was established according to research developed by Aguilera et al. [27]. Results were expressed as $\log \mathrm{CFU} / \mathrm{mL}$. The effect of each extract over the growth rate $(\mu)$ of $S$. mutans was assessed.

In addition, the minimum inhibitory concentration (MIC) was determined, which was defined as the lowest extract concentration at which the assayed bacteria did not exhibit visible growth. The BHI-broth macrodilution method and a slightly modified spectrophotometric method [28] were employed to determine the MIC. In this experiment, a strain of S. mutans (at a concentration of 103 $\log$ CFU $/ \mathrm{mL}$ ) was used, as well as two controls: negative (the strain of S. mutans and chlorhexidine) and positive (containing only the strain of S. mutans). The absorbance was read at $600 \mathrm{~nm}$ at $96 \mathrm{~h}$. The controls were prepared with BHI broth and each extract. Turbidity was defined and measured by spectrophotometry and used as a growth parameter.

\subsection{Statistical Analysis}

All trials were carried out in triplicate, and the averages were expressed. An analysis of variance was carried out with a completely randomized design, where the effects of sterilization by autoclaving on the response variables was evaluated: total phenols, total flavonoids, betalains, antioxidant activity, and antimicrobial activity against Streptococcus mutans. The analysis of means was performed by the Tukey test $(p<0.05)$; this was carried out in the statistical package SAS version 9.4. 


\section{Results and Discussion}

\subsection{Physicochemical Analyses}

Table 1 shows the physicochemical parameters of the extracts obtained for the natural sources used. The sterilization of the extracts caused an increase in the $\mathrm{pH}$, the $\mathrm{S}_{\mathrm{B}}$ value was $16.9 \%$ higher than the $S_{A}$ values, while $X_{B}$ presented an increase of $21.87 \%$ with respect to $X_{A}$. This was related to the reduction of organic acids, such as ascorbic acid. Additionally, in the autoclave-sterilized extracts, the concentration of ascorbic acid due was reduced, due to the thermolabile character of the molecule, which could explain the increase of the $\mathrm{pH}$ in the sterilized samples. [29]. The contents of the total sugars during the sterilization process in sample $S_{B}$ increased by $13.4 \%$ with respect to $S_{A}$, and the reducing sugars content increased by $33.1 \%$; however, they were not statistically different according to the Tukey test $(p<0.05)$. Meanwhile, in the $\mathrm{X}_{\mathrm{B}}$ samples, the content of total sugars increased by $13.0 \%$, and the reducing sugars by $10.98 \%$; their increase may have been due to thermal hydrolysis processes from heating during the autoclave sterilization, generating a break in the bonds of the glycosylated compounds, and increasing the concentration the concentrations of simpler sugars [30].

Table 1. Physical-chemical analysis of non-sterilized or autoclave-sterilized dragon's blood rhizome and xoconostle fruit extracts.

\begin{tabular}{ccccc}
\hline Samples & $\mathbf{p H}$ & TSC (mgGluE/g DW) & RS (mgGluE/g DW) & ASC (mgASCE/100 g DW) \\
\hline $\mathrm{S}_{\mathrm{A}}$ & $5.60 \pm 0.17 \mathrm{~b}$ & $158.20 \pm 6.40 \mathrm{c}$ & $87.10 \pm 1.28 \mathrm{c}$ & $267.30 \pm 30.07 \mathrm{~b}$ \\
$\mathrm{~S}_{\mathrm{B}}$ & $6.55 \pm 0.50 \mathrm{a}$ & $179.44 \pm 7.02 \mathrm{c}$ & $116.01 \pm 6.40 \mathrm{c}$ & $99.53 \pm 24.73 \mathrm{~d}$ \\
$\mathrm{X}_{\mathrm{A}}$ & $3.20 \pm 0.35 \mathrm{~d}$ & $503.00 \pm 26.19 \mathrm{~b}$ & $466.60 \pm 16.81 \mathrm{~b}$ & $443.70 \pm 20.84 \mathrm{a}$ \\
$\mathrm{X}_{\mathrm{B}}$ & $3.90 \pm 0.25 \mathrm{c}$ & $568.46 \pm 19.20 \mathrm{a}$ & $517.84 \pm 9.30 \mathrm{a}$ & $280.02 \pm 16.18 \mathrm{~b}$ \\
\hline
\end{tabular}

Letters in each column indicate statistically significant differences; $\mathrm{pH}$ was measured at extract concentrations of $10 \mathrm{mg} / \mathrm{mL}$ at $25.5^{\circ} \mathrm{C}$; TSC: total sugar content; RS: reducing sugars; ASC: ascorbic acid; $\mathrm{S}_{\mathrm{A}}$ : unsterilized dragon's blood rhizome extract; $\mathrm{S}_{\mathrm{B}}$ : autoclave-sterilized dragon's blood rhizome extract; $\mathrm{X}_{\mathrm{A}}$ : unsterilized xoconostle fruit extract; $\mathrm{X}_{\mathrm{B}}$ : autoclave-sterilized xoconostle fruit extract; GluE: Glucose equivalents; DW: dry weight of the sample; ASCE: ascorbic acid equivalents.

Regarding the color of the extracts, it was observed that sterilized extracts of dragon's blood became darker with an amber hue with respect to the non-sterilized extracts; this was due to the reduction of luminosity and the increase of the $b^{*}$-value, which tended to the color yellow (Table 2 ). The color change in the dragon's blood rhizome extracts could be linked to caramelization or Maillard reactions, due to the presence of sugars and the conditions of elevated temperature during the process of autoclave-sterilization [15]. The non-sterilized xoconostle extracts had a reddish coloration (greater $a^{*}$ value and lower luminosity), compared to the sterilized extracts. In the latter case, this may be due to the loss of betalains that are responsible for attributing a red coloration to the fruits of xoconostle, as also occurs in other Cactaceae fruits [8,31].

Table 2. Changes in the color of non-sterilized or autoclave-sterilized dragon's blood rhizome and xoconostle fruit extracts.

\begin{tabular}{ccccc}
\hline \multirow{2}{*}{ Samples } & \multicolumn{4}{c}{ CIELAB Color Space } \\
\cline { 2 - 5 } & $\boldsymbol{L}^{*}$ & $\boldsymbol{a}^{*}$ & $\boldsymbol{b}^{*}$ & $\boldsymbol{\Delta} \mathrm{E}$ \\
\hline $\mathrm{S}_{\mathrm{A}}$ & $35.39 \pm 0.48 \mathrm{a}$ & $11.12 \pm 0.12 \mathrm{c}$ & $43.23 \pm 0.51 \mathrm{~b}$ & \\
$\mathrm{~S}_{\mathrm{B}}$ & $29.88 \pm 0.25 \mathrm{~b}$ & $14.88 \pm 0.72 \mathrm{~b}$ & $47.49 \pm 0.71 \mathrm{a}$ & $10.24 \pm 0.43 \mathrm{~b}$ \\
$\mathrm{X}_{\mathrm{A}}$ & $24.38 \pm 0.52 \mathrm{c}$ & $32.91 \pm 0.25 \mathrm{a}$ & $25.32 \pm 0.48 \mathrm{c}$ & $33.06 \pm 1.76 \mathrm{a}$ \\
$\mathrm{X}_{\mathrm{B}}$ & $34.83 \pm 0.38 \mathrm{a}$ & $11.33 \pm 0.4 \mathrm{c}$ & $49.78 \pm 0.99 \mathrm{a}$ & \\
\hline
\end{tabular}

Letters in each column indicate statistically significant differences; $\mathrm{S}_{\mathrm{A}}$ : unsterilized dragon's blood rhizome extract; $\mathrm{S}_{\mathrm{B}}$ : autoclave-sterilized dragon's blood rhizome extract; $\mathrm{X}_{\mathrm{A}}$ : unsterilized xoconostle fruit extract; $\mathrm{X}_{\mathrm{B}}$ : autoclave-sterilized xoconostle fruit extract; $L^{*}$ : lightness; $a^{*}$ : green-red color component: $b^{*}$ : blue-yellow color component; $\Delta \mathrm{E}$ : total color difference between unsterilized and sterilized extracts. 


\subsection{Total Phenolics and Flavonoids}

Autoclave-sterilization significantly affected the concentration of phenolic compounds in dragon's blood extracts, but not of those in xoconostle fruit extracts (Table 3). It was observed that the concentrations of total phenols and flavonoids in $\mathrm{S}_{\mathrm{B}}$ increased by $95.7 \%$ and $92 \%$, respectively, almost double the amount with respect to the $S_{A}$ extracts. Randhir et al. [32] mention that heat treatment promotes the release of phenolic compounds, due to the breakdown of cell walls and cellular components such as vacuoles, and they also mention that thermal treatment dissociates conjugated polyphenols, such as tannins, to simpler phenolic compounds. In some studies where thermal treatment by autoclaving is used, samples of grain sprouts, seedlings, and legumes have also presented an increase in the total phenolic content [33,34]. Phenolic contents in extracts can be affected by extrinsic factors such as temperature, $\mathrm{pH}$, light, and oxygen content, among others [35]. In this study, the ultrasound bath that was used for rehydration of the extracts may also have had an effect on increasing the total phenol content of dragon's blood rhizome extracts. This is because ultrasound treatment causes micro-ruptures in the suspended particles via cavitation, increasing the surface area and enhancing the solubilization of phenolic compounds [36]. On the other hand, some flavonoids are stable at high temperatures. Elhamirad and Zamanipoor [37] reported that when the temperature is increased, thermal hydrolysis of glycosylated compounds occurs, increasing their solubility and modifying the diffusion coefficient, causing an increase in flavonoid content.

Table 3. Bioactive compounds and antioxidant activity in unsterilized and sterilized dragon's blood and xoconoxtle fruit extracts.

\begin{tabular}{|c|c|c|c|c|c|c|}
\hline \multirow[b]{2}{*}{ Samples } & \multirow[b]{2}{*}{$\begin{array}{c}\text { TPC } \\
\text { (mgGAE/g) }\end{array}$} & \multirow{2}{*}{$\begin{array}{c}\text { Flavonoids } \\
\text { (mgQE/g) }\end{array}$} & \multicolumn{2}{|c|}{ Total Betalains } & \multicolumn{2}{|c|}{ Antioxidant Activity } \\
\hline & & & $\begin{array}{c}\mathrm{BC} \\
(\mathrm{mg} / 100 \mathrm{~g})\end{array}$ & $\begin{array}{c}\mathrm{VXC} \\
(\mathrm{mg} / 100 \mathrm{~g})\end{array}$ & $\begin{array}{c}\text { DPPH } \\
\text { (mgTE/g) }\end{array}$ & $\begin{array}{c}\text { ABTS } \\
(\mathrm{mgTE} / \mathrm{g})\end{array}$ \\
\hline $\mathrm{S}_{\mathrm{A}}$ & $99.25 \pm 2.50 b$ & $23.59 \pm 0.5 b$ & ND & ND & $273.69 \pm 2.93 a$ & $310.68 \pm 6.81 b$ \\
\hline $\mathrm{S}_{\mathrm{B}}$ & $194.31 \pm 7.04 a$ & $45.30 \pm 0.24 a$ & ND & ND & $269.38 \pm 2.71 b$ & $345.02 \pm 10.57 \mathrm{a}$ \\
\hline $\mathrm{X}_{\mathrm{A}}$ & $24.11 \pm 1.21 c$ & $13.62 \pm 0.66 \mathrm{~d}$ & $28.64 \pm 0.96 a$ & $11.92 \pm 0.13 b$ & $42.87 \pm 0.96 b$ & $26.72 \pm 1.21 c$ \\
\hline $\mathrm{X}_{\mathrm{B}}$ & $23.53 \pm 0.23 c$ & $15.92 \pm 0.24 c$ & $4.24 \pm 0.09 \mathrm{~b}$ & $14.67 \pm 0.40 \mathrm{a}$ & $31.81 \pm 0.96 c$ & $21.83 \pm 1.49 c$ \\
\hline
\end{tabular}

Letters in each column indicate statistically significant differences; TPC: Total phenolic compounds; BC: betanin content; VXC: vulgaxathin content; $\mathrm{S}_{\mathrm{A}}$ : unsterilized dragon's blood rhizome extract; $\mathrm{S}_{\mathrm{B}}$ : autoclave-sterilized dragon's blood rhizome extract; $X_{A}$ : unsterilized xoconostle fruit extract; $X_{B}$ : autoclave-sterilized xoconostle fruit extract; GAE: gallic acid equivalents; QE: quercetin equivalents; ND: Not detected; TE: Trolox equivalents; all values were determined based on the dry weight of the sample (DW).

In this study, autoclave-sterilization did not significantly affect the content of phenolic compounds in xoconostle extracts. In contrast, the flavonoids in sterilized extracts only increased by $16.8 \%$, compared to the non-sterilized extracts. Other compounds, such as mucilage and soluble polysaccharides ( $15 \%$ found in xoconostle), may have protected the bioactive compounds under high temperatures [38,39]; this may be related to the small variation of the content of phenolic compounds in the $\mathrm{X}_{\mathrm{A}}$ extracts compared to the $\mathrm{X}_{\mathrm{B}}$ extracts. Also, other researchers state that high temperatures can increase or decrease the concentration of the phenolic compounds; these results are related to factors such as temperature, exposure time, $\mathrm{pH}$, water content, and raw material composition [40]. On the other hand, a slight increase in flavonoid content in $\mathrm{X}_{\mathrm{B}}$ compared to $\mathrm{X}_{\mathrm{A}}$ extracts may be due to the thermal stability that these present, depending on the media, chemical structures, and $\mathrm{pH}$ [37]. Also, Elhamirad and Zamanipoor [37] reported that when the temperature is increased, thermal hydrolysis of glycosylated compounds occurs, which causes an increase in the flavonoid content.

Unsterilized extracts of dragon's blood showed 75\% higher contents of phenolic compounds than non-sterile extracts of xoconostle, while sterilized extracts of dragon's blood were $87.7 \%$ higher in phenolic content than xoconostle extracts that had been sterilized by autoclaving. This may be due to the fact that in the dragon's blood plant, the roots are the first tissues that detect a water deficit condition and induce stress signals, which translate into a higher concentration of secondary metabolites in which the phenolic compounds are included [13]. Another reason could be due to the 
Maillard reaction (non-enzymatic browning), caramelization, and the chemical oxidation of phenols, since the rhizomes of dragon's blood extracts become an amber coloration (Table 2) when subjected to autoclave sterilization [32,41]. Martínez et al. [42] reported free amino acids and amines for dragon's blood rhizomes under thermal conditions; these compounds react with reducing sugars, producing other compounds with chelating and reducing properties [43]. All of the above could have an effect on increasing the quantification of total phenols in SA.

\subsection{Betalains in Xoconostle Extracts}

Measurement of the content of betalains in the dragon's blood rhizome extracts was not made, due to its absence in this species. For this reason, betalain content was only taken in xoconostle fruit extracts, where a decrease of $85.19 \%$ in the content of betanins was observed in the $X_{B}$ extracts with respect to the $X_{A}$ extracts (Table 3), while the vulgaxathin content was $23 \%$ higher in the $X_{B}$ extracts compared to $X_{A}$ extracts. The typical color loss found in the xoconostle fruit extracts subjected to high temperatures was related to a decrease in betalain and isobetanin contents (these give the red and orange coloration in xoconostle). This reduction is due to a dehydrogenation reaction in betanins and isobetanins during thermal treatments, forming compounds such as neobetanins [44]. The loss of the reddish coloration of xoconostle fruits extracts and its change to a yellow color during the process of sterilization by autoclaving may be due to the increase of neobetatins. Neobetanins have a yellow coloration, absorbing at wavelengths that are similar to vulgaxathins; therefore, their presence could be related to an observed increase of vulgaxathin content [45].

\subsection{Identification of Extracted Compounds by HPLC}

Some phenolic acids and flavonoids were detected and confirmed by HPLC in rhizomes of dragon's blood plant extracts and xoconostle fruits extracts. In the $S_{B}$ extracts, an increase of phenolic compounds was detected with respect to the $S_{A}$ extracts; this result has a behavior similar to that found in the quantification of the total content of phenols by the spectrophotometric method, where the sterilization process increased the content of the phenolic compounds. In the present study, the phenolic acids detected in $S_{A}$ and $S_{B}$ were vanillic and caffeic acids, while the flavonoids were naringenin, apigenin, and galagin (Tables 4 and 5). Wong-Paz et al. [12] analyzed ethanolic-aqueous dragon's blood rhizome extracts by HPLC; in their study, phenolic compounds were not detected due to their low concentrations and the poor purification of the extracts.

The phenolic compounds quantified in the xoconostle fruits extracts were gallic acid, vanillic acid, and p-coumaric acid, and for the flavonoids, it was only galagina. In this sense, the extract with the highest content of phenols was the xoconostle fruit extract, while the extract with the highest concentration of flavonoid compounds was the dragon's blood rhizome extract. On the other hand, in the extracts of the xoconostle fruit, the variation of the phenolic compounds was lower than in the dragon's blood rhizome extracts; $X_{B}$ extracts presented concentrations of gallic, vanillic, and p-couramic acid that were similar to that of $X_{A}$ extracts, while the flavonoid content increased in $X_{B}$ extracts (increase the content of galagin) during autoclave-sterilization treatment (Tables 4 and 5).

Some reports suggest that the presence of compounds such as caffeic, ferulic, and p-coumaric acids inhibit Gram-negative and Gram-positive microorganisms such as E. coli, S. aureus, and B. cereus [46]; the presence of these compounds could maintain the properties of antimicrobial extracts after being subjected to sterilization by autoclaving. 
Table 4. Contents of phenolic acids $(\mu \mathrm{g} / \mathrm{mL})$ in dragon's blood and xoconostle fruit extracts as detected by high-performance liquid chromatography (HPLC).

\begin{tabular}{ccccccccc}
\hline \multirow{2}{*}{ Samples } & \multicolumn{7}{c}{ Phenolic Acid Standards } \\
\cline { 2 - 8 } & GA & CGA & SA & VA & PHA & CA & FA & PCA \\
\hline $\mathrm{S}_{\mathrm{A}}$ & ND & ND & ND & $1.98 \pm 0.02 \mathrm{~b}$ & ND & $0.08 \pm 0.01 \mathrm{~b}$ & ND & ND \\
$\mathrm{S}_{\mathrm{B}}$ & $\mathrm{ND}$ & ND & ND & $3.42 \pm 0.13 \mathrm{a}$ & ND & $0.22 \pm 0.04 \mathrm{a}$ & ND & ND \\
$\mathrm{X}_{\mathrm{A}}$ & $1.53 \pm 0.06 \mathrm{a}$ & ND & ND & $1.63 \pm 0.02 \mathrm{c}$ & ND & ND & ND & $15.52 \pm 0.32 \mathrm{a}$ \\
$\mathrm{X}_{\mathrm{B}}$ & $1.42 \pm 0.04 \mathrm{~b}$ & ND & ND & $1.24 \pm 0.08 \mathrm{~d}$ & ND & ND & ND & $14.41 \pm 0.21 \mathrm{~b}$ \\
\hline $\mathrm{RP}$ & 2.5 & 4.29 & 5.10 & 5.5 & 5.71 & 6.63 & 9.36 & 9.74 \\
\hline
\end{tabular}

Letters in each column indicate statistically significant differences; $\mathrm{S}_{\mathrm{A}}$ : unsterilized dragon's blood rhizome extract; $\mathrm{S}_{\mathrm{B}}$ : autoclave-sterilized dragon's blood rhizome extract; $\mathrm{X}_{\mathrm{A}}$ : unsterilized xoconostle fruit extract; $\mathrm{X}_{\mathrm{B}}$ : autoclave-sterilized xoconostle fruit extract; RP: retention period; GA: gallic acid; CGA: chlorogenic acid; SA: syringic acid; VA: vanillic acid; PHA: p-hydroxybenzoic acid; CA: caffeic acid; FA: feluric acid; PCA: p-coumaric acid; ND: Not detected.

Table 5. Flavonoid standard content $(\mu \mathrm{g} / \mathrm{mL})$ in dragon's blood rhizome and xoconostle fruit extracts, as detected by HPLC.

\begin{tabular}{ccccccccc}
\hline \multirow{2}{*}{ Samples } & \multicolumn{7}{c}{ Flavonoid Standards } \\
\cline { 2 - 8 } & RT & PHR & MC & QE & NG & PHT & AP & GLG \\
\hline S $_{\mathrm{A}}$ & ND & ND & ND & ND & $25.45 \pm 1.05 b$ & ND & $0.96 \pm 0.03 \mathrm{~b}$ & $5.83 \pm 1.09 \mathrm{~b}$ \\
$\mathrm{~S}_{\mathrm{B}}$ & ND & ND & ND & ND & $30.66 \pm 2.96 \mathrm{a}$ & ND & $1.31 \pm 0.08 \mathrm{a}$ & $8.69 \pm 1.72 \mathrm{a}$ \\
$\mathrm{X}_{\mathrm{A}}$ & ND & ND & ND & ND & ND & ND & ND & $2.91 \pm 0.05 \mathrm{~d}$ \\
$\mathrm{X}_{\mathrm{B}}$ & ND & ND & ND & ND & ND & ND & ND & $3.58 \pm 0.25 \mathrm{c}$ \\
\hline RP & 4.4 & 6.77 & 7.57 & 10.5 & 12.25 & 13.18 & 14.63 & 22.0 \\
\hline
\end{tabular}

Letters in each column indicate statistically significant differences; $\mathrm{S}_{\mathrm{A}}$ : unsterilized dragon's blood rhizome extract; $\mathrm{S}_{\mathrm{B}}$ : autoclave-sterilized dragon's blood rhizome extract; $\mathrm{X}_{\mathrm{A}}$ : unsterilized xoconostle fruit extract; $\mathrm{X}_{\mathrm{B}}$ : autoclave-sterilized xoconostle fruit extract; RP: retention period; RT: rutin; PHR: phlorizidin; MC: myricetin; QE: quercetin; NG: naringenin; PHT: phloretin; AP: apigenin; GLG: galangin; ND: Not detected.

\subsection{Free Radical Scavenging Ability as Estimated by DPPH and ABTS}

The potential benefits that phenolic compounds have for health are attributed mainly to their antioxidant activities by donating a hydrogen atom from the aromatic hydroxyl group to free radicals [31]. In the present investigation, the in vitro antioxidant activities of rhizomes of dragon's blood plant and xoconostle fruit extracts were tested through the DPPH and ABTS assays. Table 3 shows the effect of thermal treatment by autoclaving on antioxidant activity. The antioxidant activity, according to the DPPH method, was higher in dragon's blood rhizome extracts than in xoconostle fruit extracts (Table 3). In the $\mathrm{S}_{\mathrm{A}}$ extracts, no significant difference was observed in the activity with respect to the $S_{B}$ extracts, despite the increase in the content of phenolic compounds in the $S_{B}$ samples. This was not reflected in an increase in antioxidant capacity; however, it was maintained through the autoclave-sterilization process, probably due to the loss of other antioxidant compounds such as nitrogen compounds, carotenoids, or ascorbic acid (Table 1), which contributed to the total sum of the antioxidant capacity of the extract $[29,40,47,48]$. On the other hand, some studies indicate that the reaction mechanisms of the antioxidant and DPPH depend on the structural conformation of the antioxidants [49], and these could be altered during the autoclave-sterilization process [30].

Nevertheless, a decrease of $25.7 \%$ was observed for antioxidant activity in $X_{B}$ when compared to $\mathrm{X}_{\mathrm{A}}$, and this could be related to the decrease in betanin content caused by the thermal effect (Table 3). Other thermolabile compounds with antioxidant properties, such as ascorbic acid, can be affected during sterilization by autoclaving, influencing the final activity of the extracts $[29,50]$.

The results obtained by the ABTS method indicated that $\mathrm{S}_{\mathrm{B}}$ showed a slight increase in antioxidant activity of $11 \%$ over $S_{A}$ (Table 3). This increase could be associated with an increase of phenols and flavonoids, as well as some compounds derived from color change reactions (caramelization and Maillard reactions) with the ability to chelate metals and to provide antioxidant activities [51]. 
The difference between the results observed by the ABTS method with respect to DPPH could be due to the affinity of both techniques; quantification by the ABTS method tends towards hydrophilic and lipophilic compounds, while the DPPH method tends towards slightly polar compounds [52].

With regard to the antioxidant activity by the ABTS method on xoconostle extracts, there was a decrease of $18.3 \%$ in $X_{B}$ with respect to $X_{A}$ (Table 3). The decrease in antioxidant activity in the autoclaved extracts could be attributed to the loss of thermolabile compounds such as betalain and ascorbic acid, which are present in xoconostle fruit extracts [7].

The behaviors of compounds from extracts with complex compositions cannot be predicted when they are affected by severe thermal treatments, given that the antioxidant properties can decrease or increase, due to factors such as exposure time to the thermal treatment, the temperature, the $\mathrm{pH}$ of the medium, the water activity, or the composition of the extract and its interactions, when its structure is modified [40].

\subsection{Antimicrobial Activity}

With regard to the growth kinetics of Streptococcus mutans in $\mathrm{S}_{\mathrm{A}}$ and $\mathrm{X}_{\mathrm{A}}$, growth was not observed in the latter extract (Figure 1). A similar result was obtained with the negative control (chlorhexidine). Some studies state that the contents of flavonoids, tannins, and condensed phenols of high molecular weight in dragon's blood rhizomes are responsible for the antimicrobial properties found within the extracts $[9,53]$. Other research suggests that the antimicrobial activity of dragon's blood rhizome extracts is due to the presence of terpenes such as $\beta$-sitosterol and citlalitrione [11]. The synergy among these compounds could play an important role in the antimicrobial properties found in the extracts. The results observed for the negative control (chlorhexidine) are mainly due to its cationic nature, which allows its adherence to the bacterial cell wall; at low concentrations, it increases permeability, filtrating intracellular components (bacteriostatic effect), while at high concentrations, it precipitates the bacterial cytoplasm and causes cell death (bactericidal effect) [2].

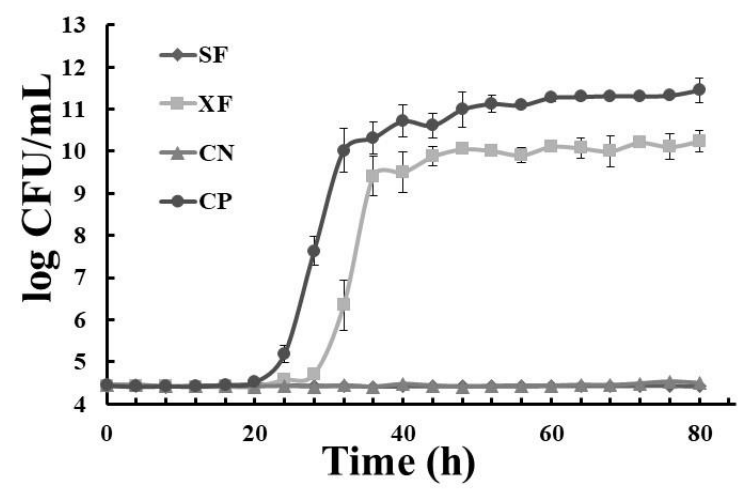

Figure 1. Growth kinetics of Streptococcus mutans in unsterilized extracts: $(\checkmark)$ dragon's blood rhizomes

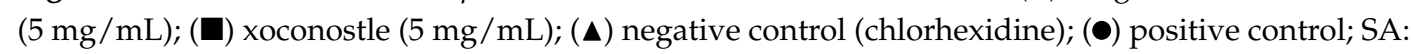
unsterilized dragon's blood rhizome extract, XA: unsterilized xoconostle fruit extract; $\mathrm{CN}$ : control negative; $\mathrm{CP}$ : control positive.

Exponential growth of S. mutans was observed after $20 \mathrm{~h}$ in the adaptation phase (Lag) in the positive control; the growth rate at the logarithmic phase was $\mu=0.487 \mathrm{~h}^{-1}\left(\mathrm{r}^{2}=0.976\right)$ (Figures 1 and 2). The non-sterilized xoconostle fruit extract $(5 \mathrm{mg} / \mathrm{mL})$ only delayed $S$. mutans growth until $4 \mathrm{~h}$, compared to the positive control during the adaptation phase (Lag); the growth rate at the logarithmic phase was $\mu=0.588 \mathrm{~h}^{-1}\left(\mathrm{r}^{2}=0.970\right)$. The antimicrobial properties of xoconostle extracts were reported by Hayek and Ibrahim [6]; however, the concentration at which xoconostle fruit extracts reported activities similar to the negative control (chlorhexidine) ranged between 28 and $80 \mathrm{mg} / \mathrm{mL}$, which is relatively high compared to the antiseptic compounds that are contained in commercial mouth 
rinses, considering that the concentrations of the active compounds in these commercial products range between 1 and $2 \mathrm{mg} / \mathrm{mL}$ [54].

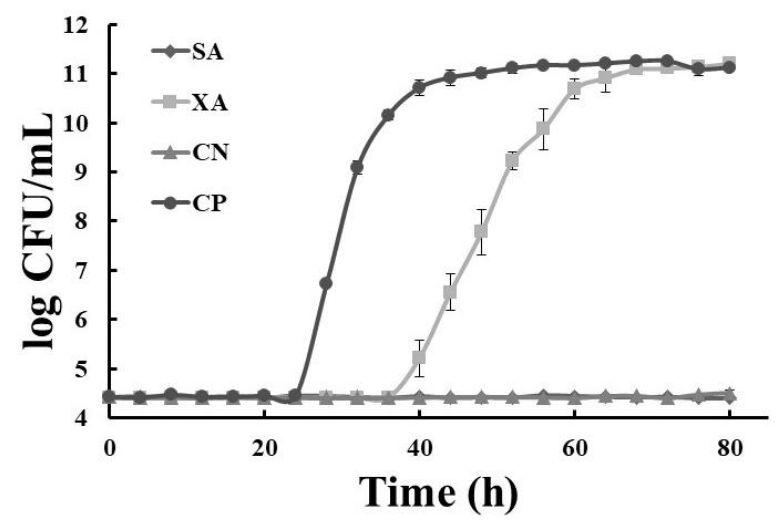

Figure 2. Growth kinetics of Streptococcus mutans in sterilized extracts by autoclave: $(\nabla)$ dragon's blood

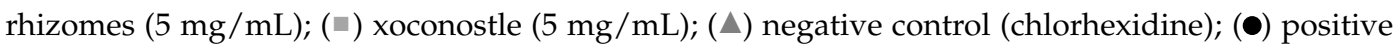
control, SB: autoclave-sterilized dragon's blood rhizome extract, XA: autoclave-sterilized xoconoxtle fruit extract; $\mathrm{CN}$ : control negative; $\mathrm{CP}$ : control positive.

The growth kinetics of $S$. mutans in $S_{B}$ and $X_{B}$ are shown in Figure 2. $S_{B}$ and $S_{A}$ extracts presented similar behaviors; the growth values $(\log \mathrm{CFU} / \mathrm{mL})$ did not vary, and thus, the temperature during the sterilization treatment did not affect the antimicrobial activity in the dragon's blood rhizome extracts. On the other hand, the growth was delayed by $12 \mathrm{~h}$ in the $X_{B}$ extracts when compared with the $\mathrm{X}_{\mathrm{A}}$ extracts during the adaptation phase (Lag), while the growth rate at the logarithmic phase in the $X_{B}$ extracts was $\mu=0.289 \mathrm{~h}^{-1}\left(\mathrm{r}^{2}=0.991\right)$. Therefore, the antimicrobial properties of the non-sterilized and autoclave-sterilized extracts of dragon's blood plant rhizomes did not change their behavior; meanwhile, the extracts of autoclave-sterilized xoconostle fruit delayed the appearance of the logarithmic phase and decreasing growth rate values $(\mu)$; however, they did not show antimicrobial activity at a concentration of $5 \mathrm{mg} / \mathrm{mL}$.

After comparisons of growth kinetics between non-sterilized and autoclave-sterilized extracts were performed, we decided to determine the MIC exclusively for the autoclave sterilized extracts (the antioxidant properties did not vary, the antimicrobial activity against S. mutans was maintained, and native microbiota were deleted from the extracts). Although filtration of the extracts through a $20 \mu \mathrm{m}$ filter is enough to remove microorganisms, sterilization by thermal treatments is usually easier to perform, in order to consider these extracts for industrial applications as antimicrobials. In that sense, only autoclave-sterilized extracts were used to calculate the MIC. The MIC value for $S_{B}$ against $S$. mutans was $2 \mathrm{mg} / \mathrm{mL}$ (Figure 3A), while for $X_{B}$, the MIC value was $28 \mathrm{mg} / \mathrm{mL}$ (Figure $3 \mathrm{~B}$ ). The antimicrobial extract of the autoclave-sterilized dragon's blood plant rhizomes showed antimicrobial activity with a lower amount of extract ( $92 \%$ less), compared to the xoconostle fruit extract; in the literature, there is no information on the antimicrobial properties of these extracts against pathogenic strains of the oral cavity, like Porphyromonas gingivalis, that are related to periodontal diseases. 

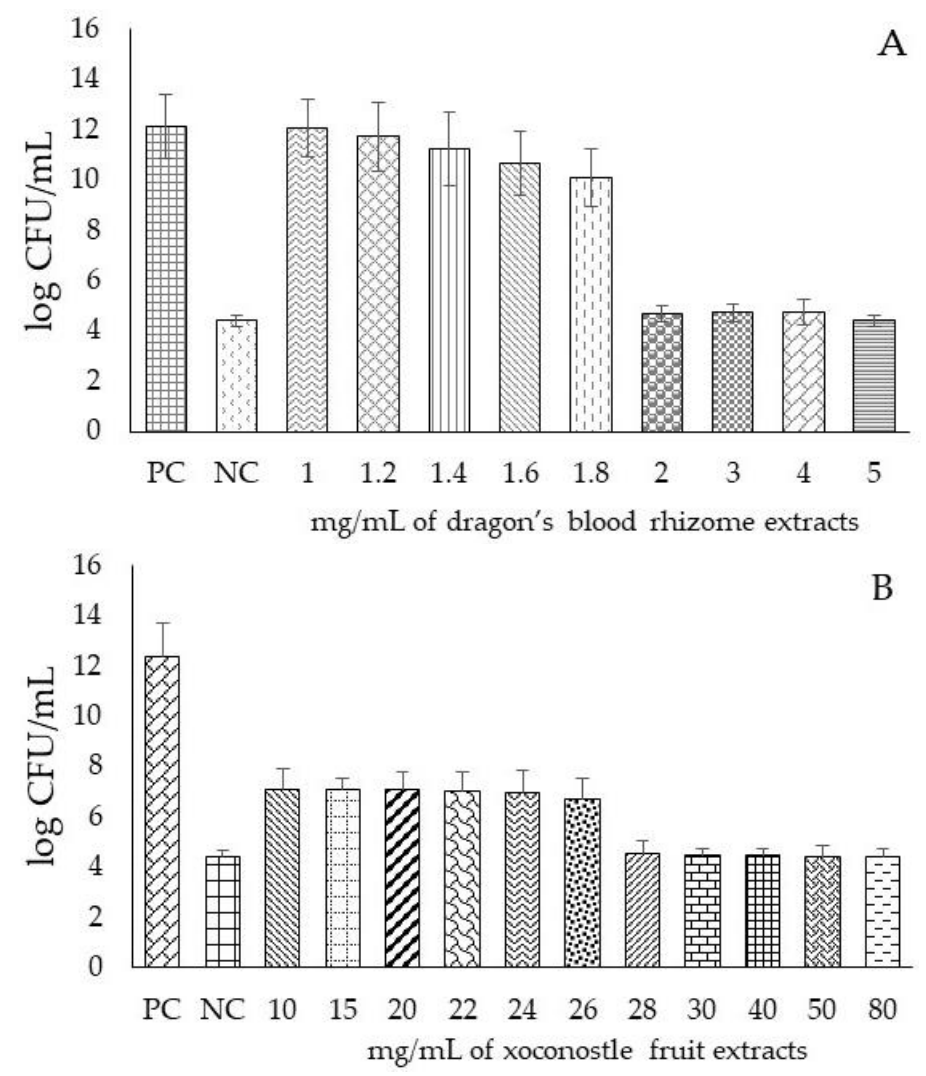

Figure 3. Log CFU/mL of S. mutans at different concentrations of dragon's blood rhizome extract (A) and different concentrations of xoconostle fruit extract (B), autoclave-sterilized and inoculated at $96 \mathrm{~h}$; PC: positive control (S. mutans); NC: negative control (chlorhexidine); the concentrations of the extracts are reported in $\mathrm{mg} / \mathrm{mL}$.

\section{Conclusions}

After the autoclave-sterilization of extracts from dragon's blood plant rhizomes and xoconostle fruit, the native microbiota were eliminated, allowing microbiological studies to be carried out without interference with the fact that the bioactive compounds were maintained after the thermal treatment. According to the HPLC method, five compounds were identified from the autoclaved dragon blood rhizome extracts, and two phenolic acids, and three flavonoids were related to antioxidant and antimicrobial properties. After sterilization treatment by autoclaving, the antimicrobial properties of the dragon fruit rhizome extract were maintained, and its low concentration for the inhibition of $S$. mutans represents an alternative to synthetic antimicrobials as an adjuvant, or to prevent oral diseases such as caries. These results suggest that an extract of autoclave-sterilized dragon's blood rhizomes could be an excellent natural source of antimicrobial compounds, as well as a safe ingredient for food or pharmaceutical products.

Author Contributions: J.T.-H., R.C.-C., E.M.S.-L., R.J.-A., C.U.L.-P., and A.D.H.-F. conceived and designed the experiments, and wrote the paper.; J.T.-H., and C.U.L.-P. performed the laboratory analyses and analyzed the data. A.D.H.-F. contributed the reagents and materials. All authors were responsible for processing information and manuscript writing. All authors read and approved the final manuscript.

Funding: This Project was funded through the National Council for Science and Technology. Award Number: 318935. Recipient: Jorge Alberto Terrazas-Hernández.

Acknowledgments: We would like to warmly thank FOMIX-CONACyT-HIDALGO (project number 195462) and CONACyT (Consejo Nacional de Ciencia y Tecnología) (grant number 318935), which gave grants to JATH and J. Jesus Martin Torres Valencia from an academic area of chemistry at the Autonomous University of the State of Hidalgo.

Conflicts of Interest: The authors declare no conflict of interest. 


\section{References}

1. Ojeda-Garcés, J.C.; Oviedo-García, E.O.; Salas, L.A. Streptococcus mutans and dental caries. Revista CES Odontología 2013, 26, 44-52.

2. Bascones-Martínez, A.; Mudarra-Morante, S. Antisépticos orales. Revisión de la literatura y prespectiva actual. Revista Clínica de Periodoncia Implantol 2006, 18, 11-39.

3. Fernández-Riverón, F.; López-Hernández, J.; Ponce-Martínez, L.M.; Machado-Betarte, C. Resistencia bacteriana. Revista Cubana de Medicina Militar 2003, 32, 44-52.

4. Benítez-Azaola, R.; García-Varela, R.; García-García, R.M.; Suárez-Jacobo, A.; Gardineau, G.A.; Altamirano, J.; Serna-Saldívar, S.O. Listeria monocytogenes growth inhibition in inoculated fresh panela cheese by the addition of Rhoeo discolor aqueous extracts combined with potassium sorbate. Revista Mexicana de Ingeniería Química 2017, 16, 425-434.

5. Waizel-Bucay, J.; Martínez-Rico, I.M. Algunas plantas usadas en México en padecimientos periodontales. Revista Asociación Dental Mexicana 2011, 68, 73-88.

6. Hayek, S.S.; Ibrahim, S.A. Antimicrobial activity of xoconostle pears (Opuntia matudae) against Escherichia coli O157:H7 in laboratory medium. Int. J. Microbiol. 2012, 2012, 368472. [CrossRef]

7. Morales, P.; Ramírez-Moreno, E.; Sánchez-Mata, M.; Carvalho, A.M.; Ferreira, I. Nutricional and antioxidant properties of pulp and seeds of two xoconostles cultivars (Opuntiajoconostle F.A.C. Weber ex Diguet and Opuntia matudae Scheinvar) of hight consumption in Mexico. Food Res. Int. 2012, 46, 279-285. [CrossRef]

8. Hernández-Fuentes, A.D.; Trapala-Islas, A.; Gallegos-Vázquez, C.; Campos-Montiel, R.G.; Pinedo-Espinoza, J.M.; Guzmán-Maldonado, S.H. Physicochemical variability and nutritional and functional characteristics of xoconostles (Opuntia spp.) accessions from Mexico. Fruits 2015, 70, 109-116. [CrossRef]

9. Wong-Paz, J.E.; Castillo-Inungaray, M.L.; López-López, L.; Contreras-Esquivel, J.C.; Nevárez-Moorillon, G.V.; Aguilar, C.N. Jatropha dioica Fuente potencial de agentes antimicrobianos. Revista Científica de la Universidad Autónoma de Coahuila 2010, 2, 1-5.

10. Mujumdar, A.M.; Misar, A.V. Anti-inflamatory activity of Jatropha curcas roots in mice and rats. J. Ethnopharmacol. 2004, 90, 11-16. [CrossRef]

11. Silva-Belmares, Y.; Rivas-Morales, C.; Viveros-Valdez, E.; Cruz-Galicia, M.G.; Carranza-Rosales, P. Antimicrobial and cytotoxic activities from Jatropha dioica roots. Pak. J. Biol. Sci. 2014, 17, 748-750.

12. Wong-Paz, J.E.; Contreras-Esquivel, J.C.; Rodríguez-Herrera, R.; Carrillo-Inungaray, M.L.; López, L.; Nevárez-Moorillón, V.; Aguilar, C.N. Total phenolic content, in vitro antioxidant activity and chemical composition of plant extracts from semiarid Mexican region. Asian Pac. J. Trop. Dis. 2015, 8, 104-111. [CrossRef]

13. Gutiérrez-Tlahque, J.; Aguirre-Mancilla, C.L.; Raya-Pérez, J.C.; Ramírez-Pimentel, J.G.; Jiménez-Alvarado, R.; Hernández-Fuentes, A.D. Effect of climate conditions on total phenolic content and antioxidant activity of Jatropha dioica Cerv. var. dioica. Ciencia e Investigación Agraria 2018, 45, 70-81. [CrossRef]

14. Hashemi, S.R.; Zulkifli, I.; Zunita, Z.; Somchit, M.N. The effect of selected sterilization method on antibacterial activity of aqueous extract of herbal plants. Biol. Sci. 2008, 8, 1072-1076. [CrossRef]

15. Yin, Q.; Mu, H.; Zeng, M.; Gao, D.; Qin, F.; Chen, J.; He, Z. Effects of heating of the total phenolic content, antioxidant activities and main functional components of simulated Chinese herb candy during boiling process. J. Food Meas. Charact. 2018, 1-11. [CrossRef]

16. AOAC International. Official Methods of Analysis, 17th ed.; AOAC International: Gaithersburg, MD, USA, 2000.

17. Dimler, R.J.; Schaefer, W.C.; Wise, C.S.; Rist, C.E. Quantitative paper chromatography of D-glucose and its oligosaccharides. Anal. Chem. 1952, 24, 1411-1414. [CrossRef]

18. Miller, G.L. Use of dinitrosalicylic acid reagent for determination of reducing sugar. Anal. Chem. 1959, 31, 426-428. [CrossRef]

19. Jagota, S.K.; Dani, H.M. A new colorimetric technique for the estimation of vitamin $C$ using folin phenol reagent. Anal. Biochem. 1982, 127, 178-182. [CrossRef]

20. Singleton, V.L.; Rossi, J.A. Colorimetry of total phenolic with phosphotungstic acid reagents. Am. J. Enol. Vitic. 1956, 16, 1444-1458. 
21. Arvouet-Grand, A.; Vennat, B.; Pourrat, A.; Legret, P. Standardization of propolis extract and identification of principal constituents. J. Pharmacie de Belgique 1994, 49, 462-470.

22. Nilsson, T. Studies into the pigments in beetroot (Beta vulgaris L. ssp. vulgaris var. rubra L.). Langbrukshogskolans Ann. 1970, 36, 179-219.

23. Aguiñiga-Sánchez, I.; Cadena-Iñiguez, J.; Santiago-Osorio, E.; Gómez-García, G.; Mendoza-Núñez, V.M.; Rosado-Pérez, J.; Ruíz-Ramos, M.; Cisneros-Solano, V.M.; Ledesma-Martínez, E.; Delgado-Bordanave, A.D.J.; et al. Chemical analyses and in vitro and in vivo toxicity of fruit methanol extract of Sechiumedule var. Pharm. Biol. 2017, 55, 1638-1645.

24. Brand-Williams, W.; Cuvelier, M.E.; Berset, C. Use of a free radical method to evaluated antioxidant activity. Food Sci. Technol. 1995, 28, 25-30.

25. Re, R.; Pellegrini, N.; Proteggente, A.; Pannala, A.; Yang, M.; Rice-Evans, C. Antioxidant activity applying an improved ABTS radical cation decolorization assay. Free Radic. Biol. Med. 1999, 26, 1231-1238. [CrossRef]

26. Domínguez, M.C.; de la Rosa, M.; Borobio, M.V. Application of a spectrophotometric method for the determination of post-antibiotic effect and comparison with viable counts in agar. J. Antimicrob. Chemother. 2011, 47, 391-400. [CrossRef]

27. Aguilera, M.C.; Romano, E.; Ramos, N.; Rojas, L. Sensibilidad del Streptococcusmutans a tres enjuagues bucales comerciales (Estudio in vitro). ODOUS Cient. 2011, 12, 7-13.

28. Salmon, S.A.; Watts, J.L.; Aarestrup, F.M.; Pankey, J.W.; Yancey, R.J. Minimum inhibitory concentrations for selected antimicrobial agents against organisms isolated from the mammary glands of dairy heifers in New Zealand and Denmark. J. Dairy Sci. 1998, 81, 570-578. [CrossRef]

29. Cuastumal-Canacuan, H.G.; Valencia-Murillo, B.L.; Ordóñez-Santos, L.E. Efectos de los tratamientos térmicos en la concentración de vitamina $\mathrm{C}$ y color superficial en tres frutas tropicales. Revista Lasallista de Investigación 2016, 13, 85-93. [CrossRef]

30. Pokorný, J. The impact of food processing in phytochemicals; the case of antioxidants. In Phytochemical Functional Foods, 1st ed.; Johnson, I., Williamson, G., Eds.; CRC Press: New York, NY, USA, 2003; Volume 1, pp. 298-312.

31. López-Palestina, C.U.; Aguirre-Mancilla, C.L.; Raya-Pérez, J.C.; Ramírez-Pimentel, J.G.; Gutiérrez-Tlahque, J.; Hernández-Fuentes, A.D. The Effect of an Edible Coating with Tomato Oily Extract on the Physicochemical and Antioxidant Properties of Garambullo (Myrtillocactus geometrizans) Fruits. Agronomy 2018, 8, 1-14. [CrossRef]

32. Randhir, R.; Kwon, Y.I.; Shetty, K. Effect of thermal processing on phenolics, antioxidant activity and health-relevant functionality of select grain and sprouts and seedling. Innov. Food Sci. Emerg. Technol. 2008, 9, 355-364. [CrossRef]

33. Beta, T.; Hwang, T. Influence of heat and moisture treatment on carotenoids, phenolic content, and antioxidant capacity of orange maize flour. Food Chem. 2018, 246, 58-64. [CrossRef]

34. Randhir, R.; Shetty, K. Mung beans processed by solid-state bioconversion improves phenolic content and functionality relevant for diabetes and ulcer management. Innov. Sci. Emerg. Technol. 2007, 8, 197-204. [CrossRef]

35. Felix, A.C.S.; Alvares, L.D.G.; Santana, R.A.; Valasques-Junior, G.L.; Bezerra, M.A.; Oliveira-Neto, N.M.; de Oliveira-Lima, E.; de Oliveira-Filho, A.A.; Franco, M.; do Nascimento-Junior, B.B. Application of experimental designs to evaluate the total phenolics content and antioxidant activity of cashew apple bagasse. Revista Mexicana de Ingeniería Química 2018, 17, 165-175.

36. Altemimi, A.; Choudhary, R.; Watson, D.G.; Lighfoot, D.A. Effects of ultrasonic treatments on the polyphenol and antioxidant content of spinach extracts. Ultrason. Sonochem. 2015, 24, 247-272. [CrossRef]

37. Elhamirad, H.A.; Zamanipoor, M.H. Thermal stability of some flavonoids and phenolic acids in sheep tallow olein. Eur. J. Lipid Sci. Technol. 2012, 114, 602-606. [CrossRef]

38. Esquivel-Gonzales, B.E.; Ochoa-Martínez, L.A.; Rutiaga-Quiñones, O.M. Microencapsulación por secado por aspersión de compuestos bioactivos. Revista Latinoamericana Tecnología Postcosecha 2015, 16, 180-192.

39. López-García, F.; Jiménez-Martínez, C.; Guzmán-Lucero, D.; Maciel-Cerda, A.; Delgado-Macuil, R.; Cabrero-Palomino, D.; Terrés-Rojas, E.; Arzate-Vázquez, I. Physical and chemical characterization of a biopolimer film made with corn starch and nopal xoconostle (Opuntia joconostle). Revista Mexicana de Ingeniería Química 2017, 16, 147-158. 
40. Shaimaa, G.A.; Mahmoud, M.S.; Mohamed, M.R.; Emam, A.A. Phytochemical screening, antioxidant activities and in vitro anticancer potential of Egyptian Capsicum spp. Biochem. Pharmacol. 2016, 5, 1-8.

41. Eichner, H. Antioxidative effect of Maillard reaction intermediates. In Progress in Food Nutrition and Science; Ericksson, C., Ed.; Pergammon Press: Oxford, UK, 1981; pp. 441-451.

42. Martínez, N.; Almaguer, G.; Vázquez-Alvarado, P.; Figueroa, A.; Zuñiga, C.; Hernández-Ceruelos, A. Análisis fitoquímico de Jatropha dioica y determinación de su efecto antioxidante y quimioprotector sobre el potencial genotóxico de ciclofosfamida, daunorrubicina y metilmetanosulfonato evaluado mediante el ensayo cometa. Boletín Latinoamericano y del Caribe de Plantas Medicinales y Aromáticas 2014, 13, 437-457.

43. Manzocco, L.; Calligaris, S.; Mastrocola, D.; Nicoli, M.; Lerici, C. Review of nonenzymatic browning and antioxidant capacity in processed food. Trends Food Sci. Technol. 2011, 11, 340-346. [CrossRef]

44. Herbach, K.M.; Stintzing, F.C.; Carle, R. Betalain stability and degradation products from purified betanin, phyllocactin and hylocerenin by high-performance liquid chromatography/electrospray ionization mass spectrometry. Rapid Commun. Mass Spectrom. 2006, 19, 2603-2616. [CrossRef]

45. Stintzing, F.C.; Herbach, K.M.; Mosshammer, M.R.; Carle, R.; Yi, W.; Sellapan, S.; Akoh, C.C.; Bunch, R.; Felker, P. Color, betalain pattern, and antioxidant properties of cactus pear (Opuntia spp.) clones. J. Agric. Food Chem. 2005, 53, 442-451. [CrossRef]

46. Rodríguez-Sauceda, E.N.; Ximhai, R. Natural antimicrobial agent use in the preservation of fruits and vegetables. Res. Gate 2011, 7, 153-170.

47. González-Cruz, L.; Hernández-Castillo, J.B.E.; Juárez-Gpiz, J.M.S.; Flores-Martínez, N.L.; Bernardino-Nicanor, A. Effect of traditional thermal treatment on the antioxidant activity and carotenoids content of nopalitos. Revista Mexicana de Ingeniería Química 2018, 17, 823-833. [CrossRef]

48. Pastene, E.R. Estado actual de la búsqueda de plantas con actividad antioxidante. Boletín Latinoamericano y del Caribe de Plantas Medicinales y Aromáticas 2009, 8, 449-455.

49. Bondet, W.; Williams, B.; Berset, C. Kinetics and mechanism of antioxidant activity using the DPPH free radical method. Lebensmittel Wissenschaft und Technologie 1997, 30, 609-615. [CrossRef]

50. Pérez-Grijalva, B.; García-Zabadúa, J.C.; Ruíz-Pérez, V.M.; Téllez-Medina, D.I.; García-Pinilla, S.; Guzmán-Gerónimo, R.I.; Mora-Escobedo, R. Biofunctionality, colorimetric coefficients and microbiological stability of blackberry (Rubusfructicosusvar. Himalaya) juice under microwave/ultrasound processing. Revista Mexicana de Ingeniería Química 2018, 8, 13-28.

51. Yu, X.; Zhao, M.; Hu, J.; Zeng, S.; Bai, X. Correspondence analysis of antioxidant activity and UV-Vis absorbance of Maillard reaction products as related to reactants. Food Sci. Technol. 2012, 46, 1-9. [CrossRef]

52. Kuskoski, M.; Asuero, A.G.; Troncoso, A.M.; Mancini-Filho, J.; Fett, R. Aplicación de diversos métodos químicos para determinar actividad antioxidante en pulpa de frutos. Ciência e Tecnologia de Alimentos 2005, 25, 726-732. [CrossRef]

53. Hu, J.; Wang, J.; Li, S.; Yang, B.; Gong, M.; Li, X.; Zhang, L.; Tian, J. Phytochemical compositions, antioxidant and antimicrobial activities analysis of extracts from Vaccinium bracteatum Thunb. Leaves. J. Appl. Bot. Food Qual. 2016, 89, 150-155.

54. Poveda-Romero, M.; Sánchez-García, S.; Medina-García, E.; Espinel-Bermúdez, M.C.; Ríos-Szalay, E.; Fernández-Pedrero, J.A. Gluconato de clorhexidina al $0.12 \%$ en la inhibición de la adherencia del Streptococcus mutans en restauraciones provisionales de polimetil metacrilato in vitro. Revista Odontológica Mexicana 2006, 10, 24-29.

(C) 2018 by the authors. Licensee MDPI, Basel, Switzerland. This article is an open access article distributed under the terms and conditions of the Creative Commons Attribution (CC BY) license (http:/ / creativecommons.org/licenses/by/4.0/). 